\title{
Biological and Environmental Drivers of Energy Allocation in a Dependent Mammal, the Antarctic Fur Seal Pup
}

\author{
Birgitte I. McDonald ${ }^{1, *}$ \\ Michael E. Goebel ${ }^{2}$ \\ Daniel E. Crocker ${ }^{3}$ \\ Daniel P. Costa ${ }^{1}$ \\ ${ }^{1}$ Department of Ecology and Evolutionary Biology, Long \\ Marine Laboratory, 100 Shaffer Road, University of \\ California, Santa Cruz, California 95060; ${ }^{2}$ Antarctic \\ Ecosystem Research Division, National Oceanic and \\ Atmospheric Administration/National Marine Fisheries \\ Service/Southwest Fisheries Science Center, La Jolla, \\ California 92038; ${ }^{3}$ Department of Biology, Sonoma State \\ University, 1801 East Cotati Avenue, Rohnert Park, \\ California 94928
}

Accepted 1/29/2012; Electronically Published 3/1/2012

\begin{abstract}
Little is known about how variation in the pattern and magnitude of parental effort influences allocation decisions in offspring. We determined the energy budget of Antarctic fur seal pups and examined the relative importance of timing of provisioning, pup traits (mass, condition, sex), and weather (wind chill and solar radiation) on allocation of energy obtained in milk by measuring milk energy intake, field metabolic rate (FMR), and growth rate in 48 Antarctic fur seal pups over three developmental stages (perinatal, premolt, and molt). The relative amount of milk energy used for growth was 59.1\% \pm $8.1 \%$ during the perinatal period but decreased to $23.4 \% \pm$ $15.5 \%$ and $26.0 \% \pm 13.9 \%$ during the premolt and molt. This decrease was associated with a greater amount of time spent fasting, along with an increase in pup activity while the mother was at sea foraging. Average daily milk intake, pup mass, and condition were all important in determining how much energy was available for growth, but the amount of energy obtained as milk was the single most important factor determining pup growth. While mean mass-specific FMR did not change with developmental stage ( range $=1.74-1.77 \mathrm{~mL} \mathrm{O}_{2} / \mathrm{g} / \mathrm{h}$ ), the factors that accounted for variation in FMR did. Weather (wind chill and solar radiation) and pup traits (mass and condition) influenced mass-specific FMR, but these impacts varied across
\end{abstract}

\footnotetext{
*Corresponding author. Present address: Scripps Institute for Oceanography, Center for Marine Biotechnology and Biomedicine, 9500 Gilman Drive, \#0204, La Jolla, California 92093-0204; e-mail: gitte.mcdonald@gmail.com.
}

Physiological and Biochemical Zoology 85(2):134-147. 2012. (C) 2012 by The University of Chicago. All rights reserved. 1522-2152/2012/8502-1070\$15.00. DOI: $10.1086 / 664948$ development. This study provides information about the factors influencing how offspring allocate energy toward growth and maintenance and improves our predictions about how a changing environment may affect energy allocation in pups.

\section{Introduction}

An important assumption in life-history theory is that greater parental effort leads to greater offspring growth and survival. For many animals the probability of surviving the first year of life is low, and the energy offspring obtain from their parents may increase their chance of survival by allowing them to be larger, have greater energy stores, and have energy available to develop foraging and survival skills (Clutton-Brock et al. 1985; Barlow and Boveng 1991). The transition to nutritional independence is a critical stage in offspring development and survival (Hauser 1994; Nislow and King 2006) because juvenile animals often lack the knowledge and motor skills to acquire food as proficiently as adults (Sullivan 1988; Weathers and Sullivan 1989). While a number of studies show postweaning survival is related to weaning mass and condition in mammals (Coulson et al. 1997; Hall et al. 2001; Beauplet et al. 2005), few studies directly measured parental energetic investment, and even fewer address how offspring use the energy they obtain from their parents (Festa-Bianchet et al. 1997, 2000; Lindström 1999). The studies that investigated energy allocation in dependent mammals often ignored the variability between individuals and the factors that account for this variability (Arnould et al. 2001, 2003). The likelihood of infants surviving this critical period is dependent on how they allocate the energy obtained from their parents toward growth and maintenance. Because juvenile survival may have a major impact on population dynamics, it is essential that we understand how they make these allocation decisions. In this study we investigate how a dependent mammal, the Antarctic fur seal pup (Arctocephalus gazella Peters), allocates energy obtained as milk toward metabolic demands and growth.

Energy budgets are important for determining how individuals and populations interact with their environment. Most studies have focused on adults, but it is also important to have knowledge on how dependent young allocate energy toward growth, energy storage, maintenance (including thermoregulation), and development of foraging skills in a manner that facilitates the successful transition to independence and thus maximizes fitness. Intrinsic factors such as offspring size, condition, and sex and extrinsic factors such as parental provi- 
sioning strategy and environment influence how dependent young allocate their energy (Blix et al. 1979; Chappell and Holsclaw 1984; Culik et al. 1989). In addition, juveniles face challenges different from those faced by adults (Barber-Meyer and Mech 2008), and juveniles have different physiological constraints (Burns and Castellini 1996; Munn and Dawson 2006), so the factors influencing juvenile and adult metabolic rates and energy budgets will likely differ. Mass-specific resting metabolic rates of juveniles are greater than those of adults both because of increased thermoregulatory costs as a result of small size and because young animals are expending energy on the synthesis of new biomass ( $\mathrm{McNab}$ 2002; Hou et al. 2008). Polar mammals are some of the most challenged because young are born with poorly developed thermoregulatory capabilities in a cold, unpredictable habitat (Blix and Steen 1979; Donohue et al. 2000). Neonates are thermally challenged because of their small size and lack of insulation and therefore spend a greater proportion of their energy budget on thermoregulation (Blix and Steen 1979; Hill 1983). Moreover, in many species juveniles expend significant amounts of energy on play behavior (Fagen 1981; Power 2000), which may be important in developing foraging ability and other survival skills (Bekoff 1988; Spinka et al. 2001).

Otariids (sea lions and fur seals) are ideal animals for investigating energy budget and energy allocation in growing offspring because females give birth to single young, all energy input is from the mother, and there is no postweaning care. They are unique in that during the dependency period the mothers alternate time on shore feeding their pups with time at sea foraging, allowing us to capture the pups with little disturbance to the mothers. In addition to the above challenges faced by juvenile animals, because breeding and feeding are separate, otariids have the added challenge of periodic fasts during the dependency period, and they are often weaned far from food sources. Hence, they must meet the additional physiological challenges of migrating to the foraging ground and then must be able to dive to forage successfully (Rutishauser et al. 2004).

Two factors that may help otariid pups in the transition to nutritional independence are lipid stores and diving ability (Burns 1999; Rutishauser et al. 2004; Richmond et al. 2006; Gastebois et al. 2011). Lipid stores can both sustain the young while looking for food and provide insulation (Young 1976; Rutishauser et al. 2004). Additionally, in otariid pups that undergo periodic fasts while their mothers are at sea foraging, it may be important to store lipid so they can survive these fasting periods (Verrier et al. 2011). Diving ability will also help pups successfully transition to independence because they will be able to access food at depth (Burns 1999; Jorgensen et al. 2001; Richmond et al. 2006). Diving ability may be enhanced by allocating energy toward lean growth (in general, larger animals are capable of longer, deeper dives) and by expending energy in activities that develop foraging skills (Gastebois et al. 2011). As otariid pups get older, they spend more time playing in water, potentially increasing foraging skills and diving capabilities (Horning and Trillmich 1997; Baker and Donohue
2000). Animals that receive more milk or have lower maintenance costs will be able to store more lipid, invest more in lean growth, and/or expend more energy in these activities, giving them an advantage at weaning (Guinet et al. 2005; Cameron 2008). However, these factors involve trade-offs. When two or more processes compete directly for a limited amount of energy, in this case activity, thermoregulation, and growth, then an increase in energy allocated to one must result in a decrease in the others. Therefore, energy allocated toward activity and thermoregulation is not available for growth and/or lipid storage.

We investigated how the magnitude and timing of milk provisioning, pup traits (size, body condition, and sex), and weather (wind chill and solar radiation) influence the offspring energy budget and its development in a high-latitude otariid, the Antarctic fur seal, by measuring field metabolic rate (FMR) and milk intake in free-ranging pups at three developmental stages. This study was conducted at Cape Shirreff, Livingston Island, Antarctica $\left(62^{\circ} 28^{\prime} \mathrm{S}, 60^{\circ} 46^{\prime} \mathrm{W}\right)$, one of the highest-latitude breeding colonies of any otariid. Because of the high latitude there is only a short period of time when conditions are mild enough for breeding, likely resulting in Antarctic fur seals having a short 4-mo lactation period. Females arrive in late November and December and give birth to a single pup weighing about $4-5 \mathrm{~kg}$. Pups are born with a natal coat that does not have the dense underfur found in adults. After parturition mothers stay on shore for 6-8 d (perinatal period) before mating and departing on the first foraging trip. During the following $4 \mathrm{mo}$, mothers will alternate foraging trips at sea with attendance visits on land. During these 4 mo, pups obtain most, if not all, of their energy from their mothers as energy-rich milk. At about 2 mo of age, pups molt the natal pelage and grow a coat much like that of adults. In late March or early April, pups wean by departing on their first foraging trip. Weather at Cape Shirreff can be challenging for fur seal pups. Temperatures are usually between $-7^{\circ}$ and $15^{\circ} \mathrm{C}$ during summer months, with an average around $2^{\circ}-3^{\circ} \mathrm{C}$. During peak pupping, daily average temperatures ranged from $-1.8^{\circ}$ to $4.1^{\circ} \mathrm{C}$. Snow cover is variable, and in most years many females are forced to pup on snow and ice. Mean wind speed in December is approximately $10-15 \mathrm{mph}$, and it is not unusual to have storms with sustained $40-50-\mathrm{mph}$ winds and precipitation.

The goals of this study were as follows. (1) Determine the energy budget of Antarctic fur seal pups-specifically, how much of the energy obtained as milk goes to meet metabolic demands (FMR) versus how much is available for growth? FMR incorporates all energetic costs, including basal metabolism, thermoregulation, and behavioral activity. (2) How efficient are pups at translating milk into growth? (3) How do intrinsic (pup size, condition, sex) and extrinsic (maternal provisioning strategy, solar radiation, wind chill) factors influence metabolic rate, and, ultimately, how much energy is available for growth? This study provides essential information on how growing pups are allocating energy and what factors influence allocation pat- 
terns, which is vital if we are to predict how they will respond to environmental change.

\section{Material and Methods}

\section{Field Methods}

This study was conducted at Cape Shirreff, Livingston Island, Antarctica, during the austral summers of 2005-2006 and 2006-2007 (referred to as 2006 and 2007). Body condition, FMR, and milk consumption measurements were collected on 48 pups of tagged females at three developmental stages: perinatal (newborn; $n=34$ ), premolt ( 1 mo of age; $n=45$ ), and molt ( 2 mo of age; $n=31$ ) using the doubly labeled water (DLW) technique and a repeated-measures study design (Costa 1987b; Donohue et al. 2002). Sample size was reduced to 34 during the perinatal period because FMR was not measured in a subset of the pups used in a concurrent study. The molt sample size was 31 measurements because some pups were lost to leopard seal (Hydrurga leptonyx Blainville) predation.

Pups were initially caught with their mothers and intubated. Milk was removed from the stomach (milk delays equilibrium and affects total body water measurements) and weighed ( $\pm 0.10 \mathrm{~kg}$; Pesola spring scale), and a $10-\mathrm{mL}$ sample of blood for background measurements ("presample") was collected from the interdigital vein of the rear flipper in an untreated serum vacutainer. The pups were given an intraperitoneal injection of a weighed dose of 18-oxygen sterile saline $(\sim 2.0 \mathrm{~mL} /$ $\mathrm{kg} 10 \%{ }^{18} \mathrm{O}$; Cambridge Isotope Laboratories, Andover, MA), immediately followed by an intramuscular injection of a weighed dose of deuterated water in $2006(0.2 \mathrm{~mL} / \mathrm{kg} 99.9 \%$ ${ }^{2} \mathrm{H}$; Cambridge Isotope Laboratories) or tritiated water (HTO) in 2007 (1.5 mL of 7.5 MBq/mL ${ }^{3} \mathrm{H}$; American Radiolabeled Chemicals, St. Louis, MO). Pups were held for $3 \mathrm{~h}$ to ensure complete equilibration of the isotopes, and a $10-\mathrm{mL}$ blood sample was collected ("equilibrium sample") to determine total body water (TBW) and initial ${ }^{18} \mathrm{O}$ and ${ }^{2} \mathrm{H}$ (or ${ }^{3} \mathrm{H}$ levels), before the pups were returned to their mothers. Pups were recaptured 24-48 h after their mother departed on her first trip to sea to ensure they were postabsorptive and had no milk in their stomachs. Once again they were weighed, and a 10-mL blood sample was collected ("final sample") to determine the isotope turnover during the study period in order to calculate $\mathrm{CO}_{2}$ production.

Measurements were collected on the same pups at 1 and 2 mo of age to determine body condition, FMR, and milk composition. Pups were weighed and a background blood sample (presample) was collected (to correct for residual isotope from previous sampling interval in the TBW calculation) at least 24 $\mathrm{h}$ after the mother departed to sea. Subsequently, they were injected with DLW as described above, and $3 \mathrm{~h}$ later an equilibration blood sample was collected to determine TBW and initial ${ }^{18} \mathrm{O}$ and ${ }^{2} \mathrm{H}\left(\right.$ or $\left.{ }^{3} \mathrm{H}\right)$ levels. The mother returned and fed her pup for 1-3 d. One to two days after the female departed again, the pup was recaptured and weighed, and a blood sample was collected. This allowed us to measure milk intake and pup metabolic rate over the course of a single attendance visit. All blood samples were centrifuged at 3,000 rpm shortly after collection and serum samples frozen at $-20^{\circ} \mathrm{C}$ for later analysis.

Females were caught with their pups $1 \mathrm{~d}$ postpartum, anesthetized, measured, and weighed ( $\pm 0.2 \mathrm{~kg}$; Dynalink Systems International), milk samples collected $(n=42)$, and VHF radio transmitters $(55 \mathrm{~mm} \times 22 \mathrm{~mm} \times 10 \mathrm{~mm}, 23 \mathrm{~g}$; Advanced Telemetry Systems, Isanti, MN) attached to the fur using 5min epoxy. Additionally, some of the females were recaptured to collect milk samples approximately $5 \mathrm{~d}(n=11), 1$ mo $(n=10)$, or 2 mo $(n=21)$ postpartum.

Foraging trip duration and attendance of radio-tagged females was monitored by an automatic receiving station. The station scans each radio frequency for $30 \mathrm{~s}$ every $30 \mathrm{~min}$. This allowed determination of foraging trip and attendance visit duration to within $1 \mathrm{~h}$. A foraging trip was considered to be any gap of $8 \mathrm{~h}$ or more that included nighttime hours. This was based on the diving behavior of females in previous studies using time-depth recorders (U.S. Antarctic Marine Living Resources Program, unpublished data) and confirmed for females that also carried time-depth recorders in this study (McDonald et al. 2009).

Animal use was completed under National Marine Fisheries Service permit 774-1649. All procedures were approved by the University of California, Santa Cruz, Animal Use Committee.

\section{Weather Data}

A weather station was located approximately $100 \mathrm{~m}$ from breeding colonies and within the area used by pups later in the season. A Davis Weather Monitor II station with a temperature sensor and anemometer archived temperature (accuracy: $\pm 0.5^{\circ} \mathrm{C}$, resolution: $0.1^{\circ} \mathrm{C}$ ) and wind speed (accuracy: $\pm 2 \mathrm{mph}$, resolution: $\pm 1 \mathrm{mph}$ ) at 15 -min intervals (Davis Instruments, Hayward, CA). Temperature and wind speed were sampled every $8 \mathrm{~s}$, and the averaged value for each 15-min interval was archived. A Hobo Micro Station data logger with a silicon pyranometer (solar radiation) smart sensor archived average light intensity for each 15-min interval (Onset Hobo, Bourne, MA). We averaged wind chill $\left( \pm 0.1^{\circ} \mathrm{C}\right)$ and solar radiation/ day $\left( \pm 0.1 \mathrm{~W} / \mathrm{m}^{2} / \mathrm{d}\right)$ over each individual's study period (time between equilibrium sample on initial capture and final sample at recapture).

\section{Sample Analysis}

Pup serum samples were distilled in duplicate using the method of Ortiz et al. (1978). The ${ }^{3} \mathrm{H}$ activity of samples was determined by counting $100 \mu \mathrm{L}$ of sample in $5 \mathrm{~mL}$ of scintillation cocktail with a Beckman model LS 3801 liquid scintillation counter. Subsamples of injectant were diluted and counted at the same time to determine the specific activity of the HTO injected. ${ }^{2} \mathrm{H}$ and ${ }^{18} \mathrm{O}$ enrichment levels of 2006 samples were determined in duplicate by the University of California, Davis, Stable Isotope Facility with a Los Gatos liquid water isotope analyzer, model DLT-100 (Los Gatos Research, Mountain View, CA), which is based on high-resolution direct-absorption spectroscopy. ${ }^{18} \mathrm{O}$ 
enrichment of 2007 serum samples was determined by Metabolic Solutions (Nashua, NH) using gas isotope ratio mass spectrometry. Subsamples of injectant were sent to both labs to determine the enrichment of injectant. Five replicate enriched samples were sent to both labs for cross-validation of results, and there were no significant differences in the results between the labs (\% difference between two labs: ${ }^{2} \mathrm{H}=3.2 \%$, $\left.{ }^{18} \mathrm{O}=2.8 \%\right)$.

\section{FMR, Milk Intake, and Energy Budget Calculations}

Body composition was determined by calculating TBW from the dilution of ${ }^{18} \mathrm{O}$ labeled water using the following equation:

$\mathrm{TBW}=$

enrichment of injectant $\times$ injection volume

enrichment of equilibrium sample - enrichment of presample

For newborn pups, percent total body lipid was calculated from TBW using the equation percent total body lipid $=66.563-$ 0.845 TBW\%. This was derived empirically for Antarctic fur seal pups of a similar age (Arnould et al. 1996b). Because these data were not available for older pups, the lean body mass of pups at 1 and 2 mo of age was calculated from TBW assuming a hydration value of lean tissue of 74.7\% (Arnould et al. 1996b). Lipid was assumed to be anhydrous (Costa 1987a). Using the above hydration values, we calculated total body lipid using $\mathrm{TBL}=M_{\mathrm{b}}-1.34 \times \mathrm{TBW}$, where $M_{\mathrm{b}}$ is body mass $(\mathrm{kg})$ and TBL is total body lipid.

Total water influx rates were calculated from the decrease in specific activity of ${ }^{3} \mathrm{H}$ (or ${ }^{2} \mathrm{H}$ ) using equations (5) and (6) in Nagy and Costa (1980). $\mathrm{CO}_{2}$ production was calculated using both a single-pool equation (Nagy and Costa 1980, eq. [3]) and two-pool equation (Speakman 1997, p. 315, sec. h). $\mathrm{CO}_{2}$ production from the single-pool equation was used to calculate daily energy expenditure (DEE) and metabolic water production in pups because single-pool equations are best for small animals, and the Nagy equation allows for change in mass, which is appropriate for growing pups (Speakman 1997). DEE was calculated from $\mathrm{CO}_{2}$ production using a conversion factor of $27.44 \mathrm{~kJ} / \mathrm{L} \mathrm{CO}_{2}$ (Costa $1987 a$ ), assuming a respiration quotient of 0.7 based on a diet of milk (Schmidt-Nielsen 1979; Costa 1987a). Metabolic water production was calculated from the metabolic rate assuming a conversion factor of $0.0263 \mathrm{~g}$ $\mathrm{H}_{2} \mathrm{O} / \mathrm{kJ}$ (Schmidt-Nielsen 1979; Donohue et al. 2002).

Milk consumption rates were calculated using total water influx, metabolic water production values calculated for each individual pup, and the mean water and energy content of milk sampled from study females during the perinatal period and 1 and 2 mo postpartum (McDonald 2009). Briefly, milk water and energy content were measured in duplicate using the ovendrying method and bomb calorimetry. There were no significant maternal age and year differences in water or energy content, so data from all animals were combined $(P>0.05$ for all pup age categories). Mean percent milk water content for the perinatal $(n=42)$, premolt $(n=10)$, and molt $(n=21)$ periods used in calculations were $47.7 \% \pm 4.9 \%, 51.6 \% \pm 7.4 \%$, and $45.3 \% \pm 6.2 \%$, respectively, and mean energy content values were $17.74 \pm 1.85,15.82 \pm 2.86$, and $18.37 \pm 2.30 \mathrm{~kJ} / \mathrm{g}$, respectively (McDonald 2009), similar to values measured in other populations of Antarctic fur seals (Arnould and Boyd 1995).

Milk intake was calculated for each pup using the following equation (Ortiz et al. 1984):

milk intake rate $=$

total water influx - metabolic water production milk water content (\%)

Milk intake was converted to energy consumed using the energy content of milk determined for each age category. The amount of milk energy ingested per study period (total milk energy intake during visit, $\mathrm{MJ}$ ) was calculated as the milk intake rate multiplied by the sampling interval (time between equilibrium sample at initial capture and final sample at recapture). Rate of milk energy intake over the perinatal period was calculated by dividing total energy intake during a visit by the number of days the female was on land (milk energy intake rate, MJ/ d). Additionally, for the 1 and 2 mo of age measurements, average daily milk consumption over the trip/visit cycle (daily milk intake over trip/visit cycle, MJ/d) was calculated by dividing total energy transfer during a visit by trip/visit cycle duration. The trip/visit cycle duration is the duration of the attendance visit where measurements were collected and the preceding foraging trip (trip/visit cycle $=$ trip duration [time at sea] + attendance duration [time on land]).

Assimilation efficiencies of suckling fur seal pups is unknown, but based on assimilation studies in other species we assumed that $5 \%$ of ingested energy was lost in urine and feces (Oftedal and Iverson 1987; Fadely et al. 1990; Donohue et al. 2002). Based on this assumption, milk energy was adjusted to account for loss of energy in urine and feces. Percent of energy ingested available for growth was calculated using

$$
\begin{gathered}
\text { energy for growth }(\%)= \\
\frac{\text { adjusted milk energy intake - energy expenditure }}{\text { adjusted milk energy intake }}
\end{gathered}
$$

where energy expenditure during the perinatal period or during a foraging cycle is calculated by multiplying DEE by days of perinatal period or trip/visit cycle duration. Growth efficiency was calculated by dividing pup growth during the study period (g) by the amount of energy ingested (MJ).

\section{Statistical Analysis}

Separate general linear models (GLMs) for each age category were used to investigate the influence of pup traits, weather, and provisioning strategy on mass-specific FMR and energy available for growth at different stages of the postnatal period (Cran R 2.12.2, package stats). In all models the independent 


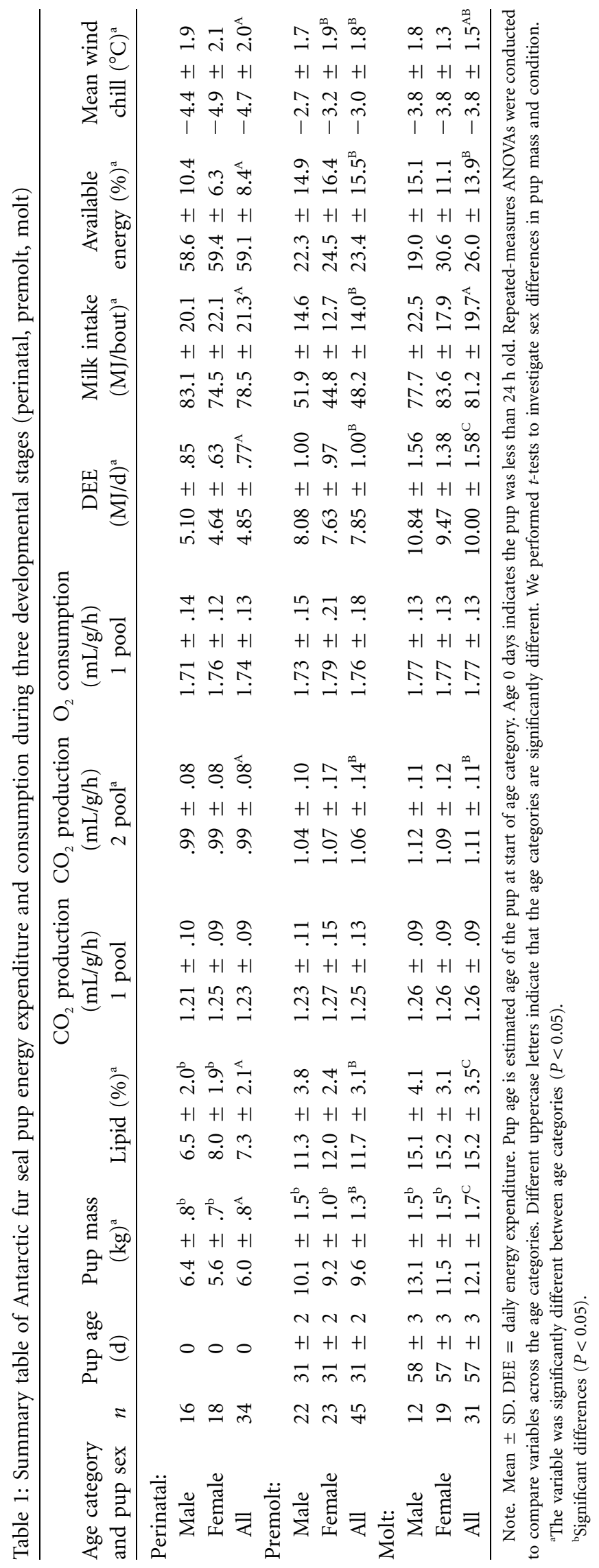



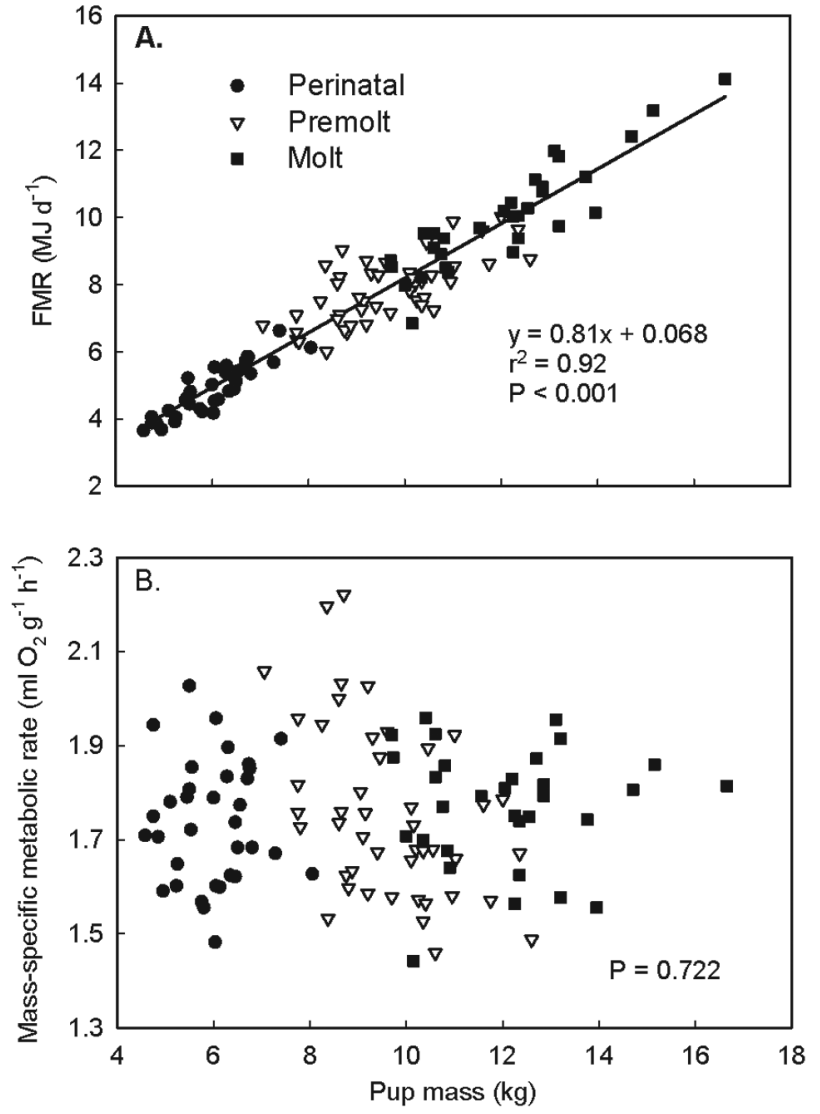

Figure 1. The relationship between pup mass and $(A)$ whole-animal field metabolic rate (FMR; MJ/d) and (B) mass-specific FMR ( $\mathrm{mL} \mathrm{O}_{2} /$ $\mathrm{g} / \mathrm{h}$ ) in Antarctic fur seal pups at Cape Shirreff, Livingston Island, Antarctica. Metabolic measurements were collected at three developmental age categories: perinatal, premolt, and molt. Larger pups have greater whole-animal FMR $\left(F_{1,108}=1,197.50, P<0.001\right)$, but there was no difference in mass-specific FMR between the age categories (Wilks's $\left.\lambda=0.87, F_{2,20}=1.49, P=0.250\right)$.

variables were pup mass, pup condition, pup sex, wind chill, solar radiation, perinatal period or trip/visit cycle duration, daily milk intake rate, study year, and four interaction terms (pup mass $\times$ wind chill, pup mass $\times$ solar radiation, pup condition $x$ wind chill, and pup condition $\times$ solar radiation). GLMs were also performed to examine the relationship between pup sex or mass and body condition for each age category. Models were compared using the corrected Akaike Information Criterion (AICc), and effects were dropped if the simplified model had a lower AICc value using a backward stepwise procedure. Residual plots were examined to assess model fit (Zuur et al. 2009). If the full model did not explain variation in the dependent variable and dropping variables did not lower the AICc value, we concluded there were no strong models and the factors we measured did not explain the variation in the dependent variable.

Repeated-measure ANOVAs were used to investigate differences in pup traits, FMR, and energy budgets between age categories. If significant, Bonferroni-corrected pairwise comparisons were conducted to determine which age categories differed. Data were tested for normality, homogeneity of variances, and multicollinearity before analysis when necessary. Variance inflation factors of independent variables in models were evaluated to assess multicollinearity and were $<2.5$ in all final models, indicating there was no correlation between variables. All results are expressed as mean \pm SD. Results were considered significant at the $P<0.05$ level.

\section{Results}

As expected, pup mass and body condition increased as the pups got older (table 1). Additionally, male pups were heavier than female pups in each age category (table $1 ; P<0.05$ ). However, there was no relationship between pup mass or sex and body condition $(P>0.05)$, except during the perinatal period, when females had significantly more lipid than male pups (table $\left.1 ; F_{1,32}=5.10, P=0.031\right)$.

\section{Field Metabolic Rate}

The mass-specific FMR calculated using the single-pool and two-pool methods were significantly different (table 1; paired $t$-test: perinatal, $t=20.2, P<0.001$; premolt, $t=17.9, P<$ 0.001 ; molt, $t=15.3, P<0.001)$. The two-pool method produced significantly lower mass-specific FMRs, potentially because it did not take into account the changing mass of pups. Therefore, we used single-pool results for all calculations and analysis.

Whole-animal FMR (MJ/d) increased significantly with age as pups increased in size (Wilks's $\lambda=0.02, F_{2,21}=494.0$,

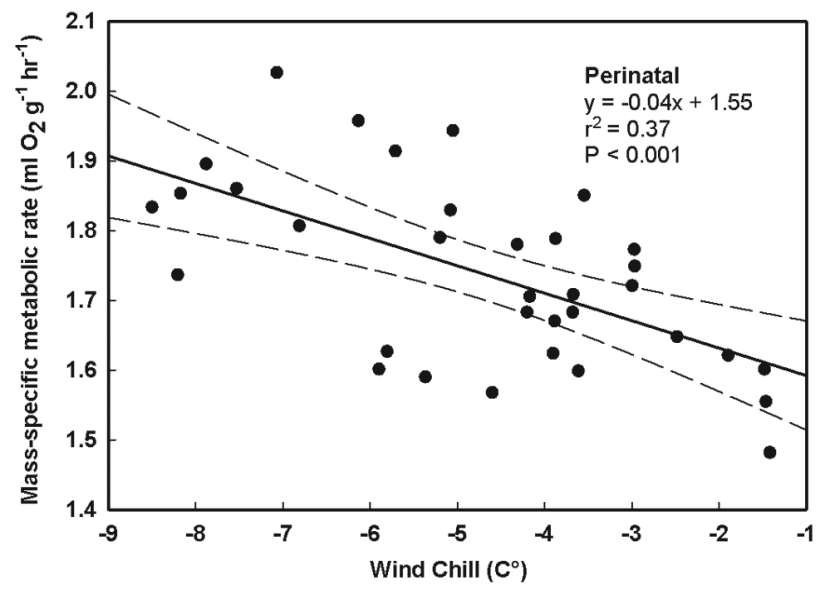

Figure 2. Mass-specific field metabolic rate decreases in warmer weather conditions during the perinatal age category $\left(F_{1,32}=18.48\right.$, $P<0.001)$. Full model included pup mass, pup condition, pup sex, wind chill, solar radiation, milk intake rate, trip/visit cycle duration, study year, and four interaction terms (pup mass $x$ wind chill, pup mass $\times$ solar radiation, pup condition $\times$ wind chill, and pup condition $\times$ solar radiation). Only wind chill was retained in the best model. 


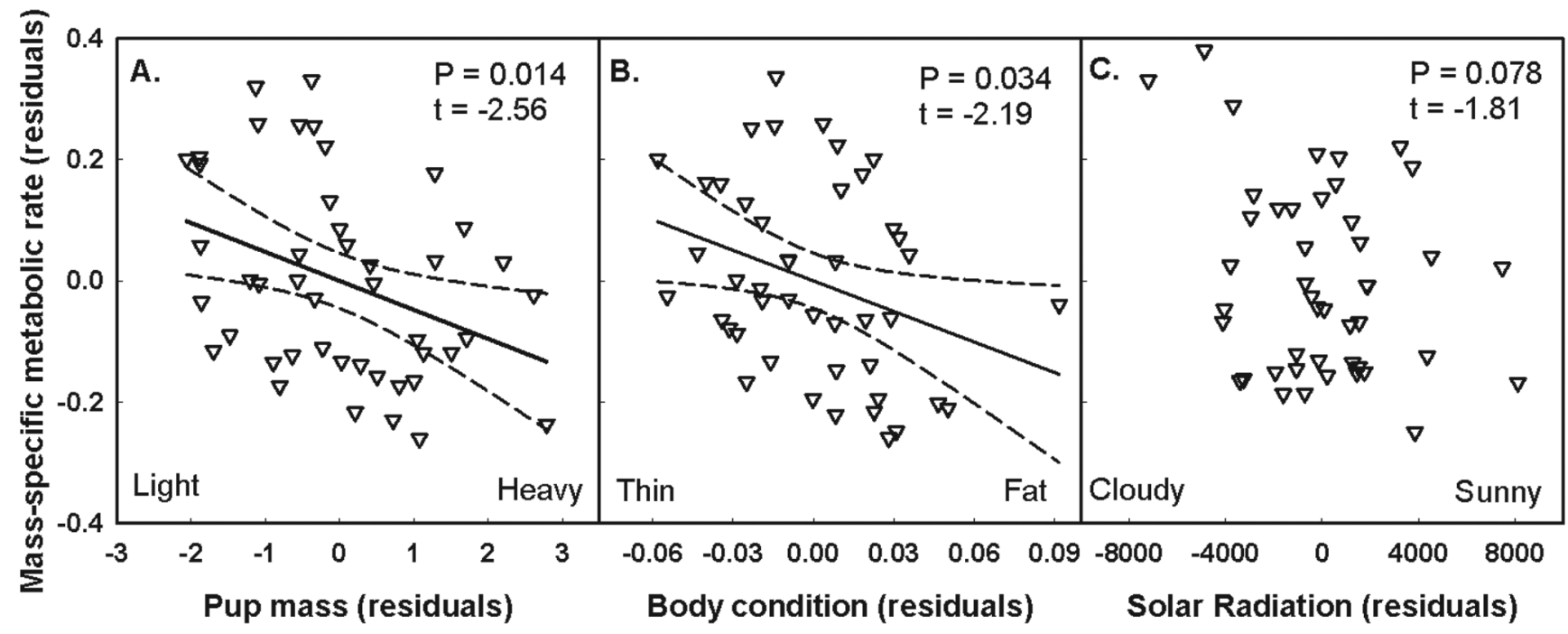

Figure 3. Partial residual plots showing the negative relationship between $(A)$ pup mass and $(B)$ condition to mass-specific field metabolic rate during the premolt age category $\left(R^{2}=0.34, F_{3,41}=6.92, P<0.001\right.$; pup mass, $\eta^{2}=0.14$; body condition, $\eta^{2}=0.10$; solar radiation, $\eta^{2}=$ 0.07). $C$, Solar radiation was in the best model but was not significant. Full model included pup mass, pup condition, pup sex, wind chill, solar radiation, milk intake rate, trip/visit cycle duration, study year, and four interaction terms (pup mass $\times$ wind chill, pup mass $\times$ solar radiation, pup condition $\times$ wind chill, and pup condition $\times$ solar radiation).

$P<0.001$; table 1). Pup mass accounted for most of the variation in whole-animal FMR $\left(r^{2}=0.92, F_{1,108}=1,197.50, P<\right.$ 0.001; fig. $1 A$ ). To examine factors that influence the variation in FMR not accounted for by size, we used mass-specific FMR in the models examining the influence of pup traits, weather, and provisioning strategy on FMR. Repeated-measure ANOVAs indicated that there was no difference in mass-specific FMR between the age categories (Wilks's $\lambda=0.87, F_{2,20}=1.49$, $P=0.250$; table 1 ; fig. $1 B)$.

For the perinatal age category, the most parsimonious model explaining variation in mass-specific FMR contained only wind chill, indicating that at this age weather influences metabolic rate, with pups experiencing colder average temperatures having the highest metabolic rates $\left(r^{2}=0.37, F_{1,32}=18.48, P<\right.$ 0.001 ; fig. 2). This model accounted for $36.6 \%$ of the variation in mass-specific FMR. At 1 mo of age the most parsimonious model included pup mass, body condition, and solar radiation, but all of the variables had a small effect $\left(R^{2}=0.34, F_{3,41}=\right.$ 6.92, $P<0.001$; pup mass, $\eta^{2}=0.14$; body condition, $\eta^{2}=$ 0.10 ; solar radiation, $\eta^{2}=0.07$; fig. 3 ). Heavier pups with a greater percentage of lipid tended to have lower mass-specific FMRs (fig. 3). During the molt (2 mo of age), there were no strong models, indicating that the factors measured did not account for much of the variation in mass-specific FMR.

\section{Energy Available for Growth}

The percentage of milk energy available for growth was $59.1 \% \pm 8.1 \%, 23.4 \% \pm 15.5 \%$, and $26.0 \% \pm 13.9 \%$ during the perinatal, premolt, and molt age categories, respectively (table 1). Percentage of available energy was significantly different between the age categories (Wilks's $\lambda=0.15, F_{2,18}=$ 50.76, $P<0.001$ ), and post hoc tests indicated that significantly more energy was available during the perinatal period.

Variables influencing the percentage of energy available for growth were examined separately for each age category. For all age categories, the best model included pup mass and milk intake rate (figs. 4, 5). Larger pups had less energy available for growth because of their greater whole-animal FMR (figs. 4, $5 A$ ). The amount of energy available for growth increased with average daily milk intake, as one would predict (figs. 4, 5B). For the premolt age category, the best model also included body condition and trip/visit duration (fig. 5). The amount of energy available for growth increased in pups with more lipid (which is consistent with the mass-specific FMR model results that found pups with more fat had lower mass-specific FMRs). There was also a positive trend for pups of females exhibiting a longer trip/visit cycle duration to have more energy available for growth, but this was not significant in the model and had a small effect $\left(\eta^{2}=0.09\right.$; fig. $\left.5 D\right)$.

\section{Relationship between Energy Intake and Growth Rate}

There was a significant positive relationship between milk intake and growth rate during all age categories (fig. 6). During the perinatal period, average daily milk intake accounted for $58.5 \%$ of the variation in growth rate $\left(F_{1,34}=47.92, P<\right.$ 0.001; fig. 6A). Daily milk intake explained $38.9 \%$ and $64.0 \%$ of the variation in growth during the premolt and molt periods, respectively (premolt, $F_{1,42}=26.784, P<0.001 ;$ molt, $F_{1,27}=$ 


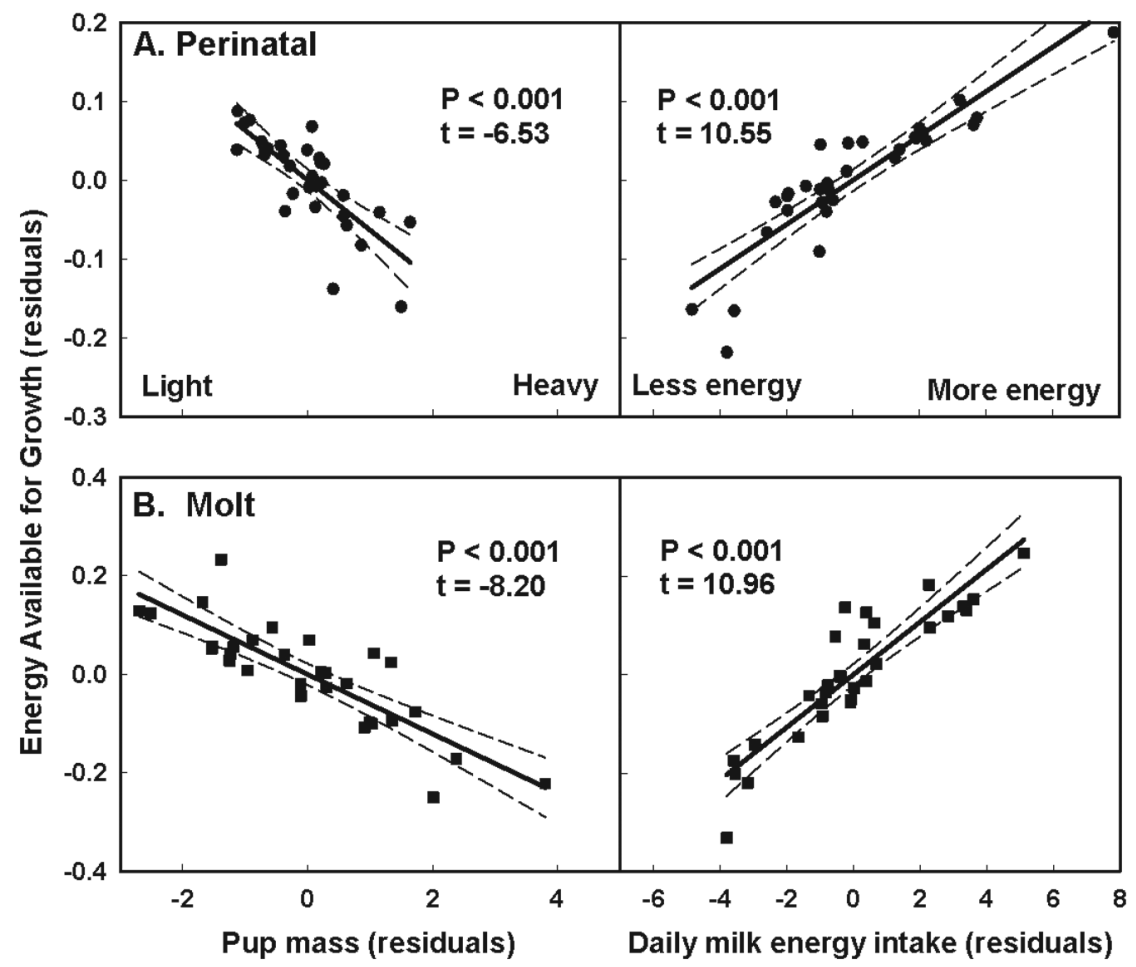

Figure 4. Partial residual plots showing the negative relationship between pup mass and energy available for growth (\%) and the positive relationship between daily milk intake rate and energy available for growth $(\%)$ during $(A)$ the perinatal period $\left(n=31, R^{2}=0.81, F_{2,28}=\right.$ 58.34, $P<0.001$; pup mass, $\eta^{2}=0.60$; milk intake rate, $\left.\eta^{2}=0.80\right)$ and $(B)$ the molt period $\left(n=30, R^{2}=0.83, F_{2,27}=65.67, P<0.001\right.$; pup mass, $\eta^{2}=0.71$; milk intake rate, $\eta^{2}=0.82$ ). Full model included pup mass, pup condition, pup sex, wind chill, solar radiation, milk intake rate, trip/visit cycle duration, study year, and four interaction terms (pup mass $x$ wind chill, pup mass $x$ solar radiation, pup condition $\times$ wind chill, and pup condition $\times$ solar radiation). Only the best model for the perinatal and molt age categories is presented.

47.70, $P<0.001$; fig. $6 B, 6 C)$. Although milk intake was positively related to growth for each age category, growth efficiency decreased as the pups got older (Wilks's $\lambda=0.21, F_{2,18}=$ 34.33, $P<0.001$; fig. 6). Growth efficiency was $16.2 \pm 4.1$, $12.1 \pm 7.5$, and $5.8 \pm 5.6 \mathrm{~g} / \mathrm{MJ}$ during the perinatal, premolt, and molt developmental stages, respectively.

\section{Discussion}

\section{Energy Budgets and FMR}

This is one of the first studies to investigate the factors influencing FMR and energy budgets in wild dependent young. We found that the amount of energy available for growth varied across developmental stages. Because pups were not very active or fasting during the perinatal period (B. I. McDonald, personal observation), more of the ingested milk energy (60\%) was available for growth compared to the premolt and molt periods. At 1 and 2 mo of age, when pups were undergoing regular fasts and were more active (spending over $20 \%$ of the time in water by 6 wk of age; B. I. McDonald and M. E. Goebel, unpublished data), only $\sim 25 \%$ of energy intake was available for growth. California sea lion (Zalophus californianus Lesson) pups exhib- ited a similar decrease in energy available for growth between their first and second months of life, likely for similar reasons (Oftedal et al. 1987). In contrast, some species showed an increase in the proportion of energy available for growth with age (Green et al. 1988; Merchant et al. 1996; table 2). If the current study had extended to the period after pups completed molting, when pups are larger and have an adult coat, pups might have allocated more energy toward growth/storage, as seen in other species (Merchant et al. 1996; Donohue et al. 2002).

In contrast to otariids, phocid pups allocate a much greater proportion of the energy obtained from their mothers toward growth/energy storage (table 2). This is not surprising considering the phocid lactation strategy, where mothers stay with their pups throughout all (or most) of the dependency period. This allows mothers to quickly transfer energy to the pup during an abbreviated lactation period (4 d-6 wk; Costa 1993). Based on mass transfer studies, most phocid pups store $50 \%$ $70 \%$ of the energy obtained from their mothers (table 2). These values are comparable to the perinatal values measured in this study $(59.4 \% \pm 8.5 \%)$, when mothers stay with young pups 


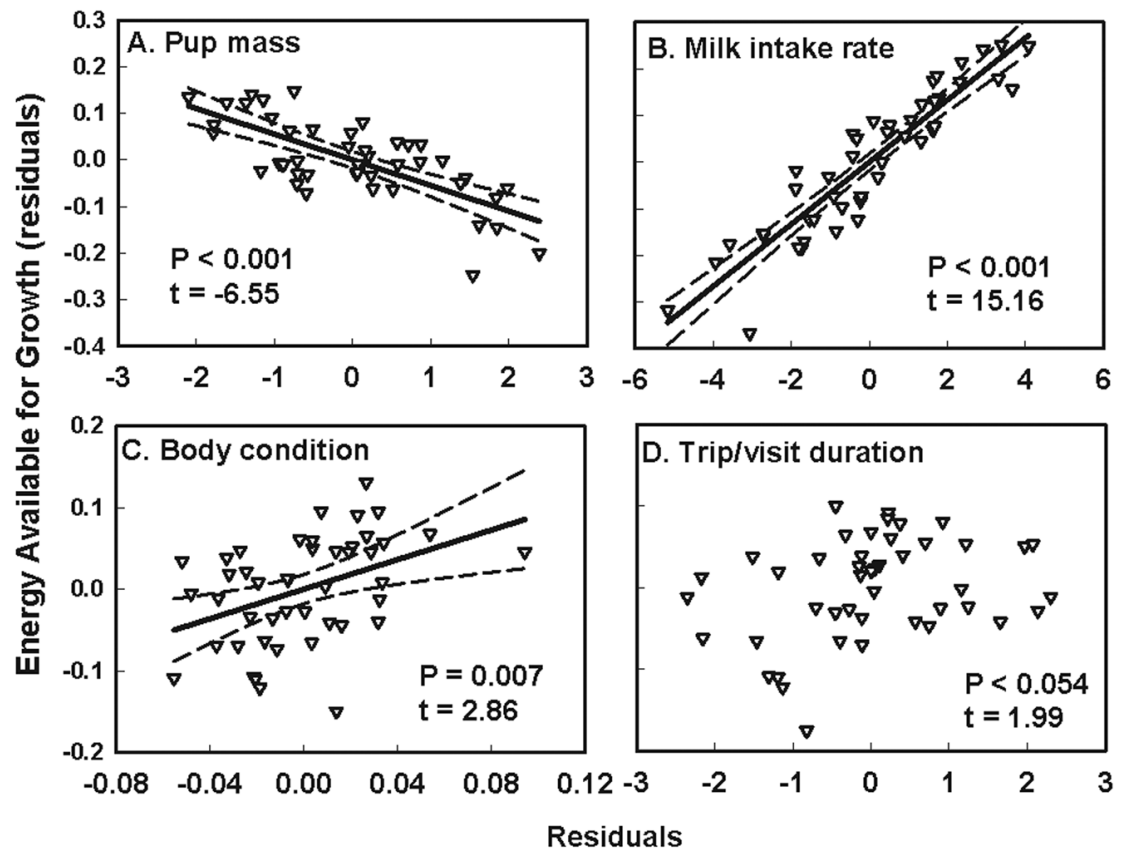

Figure 5. Partial residual plots showing the relationship between $(A)$ pup mass, $(B)$ milk intake rate, $(C)$ condition, and $(D)$ trip/visit duration to energy available for growth during the premolt age category $\left(\% ; n=45, R^{2}=0.86, F_{4,40}=59.03, P<0.001\right.$; pup mass, $\eta^{2}=0.52$; milk intake rate, $\eta^{2}=0.85$; body condition, $\eta^{2}=0.17$; trip/visit duration, $\eta^{2}=0.09$ ). Full model included pup mass, pup condition, pup sex, wind chill, solar radiation, milk intake rate, trip/visit cycle duration, study year, and four interaction terms (pup mass $\times$ wind chill, pup mass $\times$ solar radiation, pup condition $\times$ wind chill, and pup condition $\times$ solar radiation). Only results from the best model are presented.

for an extended period, but generally, otariids tend to exhibit a growth strategy similar to nonphocid mammals (table 2).

In addition to the decrease in the amount of energy going toward growth as pups age, whole-animal FMR increased as expected because of increasing pup size; however, mass-specific FMR did not change with age category. Typically, mass-specific FMR decreases as animals get larger and older (McNab 2002). Additionally, we anticipated that neonates born in a challenging environment would have elevated FMRs and that as they increased their thermoregulatory capabilities, mass-specific FMR would decrease (McNab 2002). Contrary to predictions, there was no decrease in FMR with increasing age. FMR incorporates all energetic costs including basal metabolism, thermoregulation, and behavioral activity, so although pups may have changed how they allocated energy toward thermoregulation and activity, mass-specific FMR remained constant. In northern fur seals (Callorhinus ursinus Linnaeus), mass-specific FMR increased between the premolt and molt age categories, and this was attributed to the costs of pelage growth and increased activity (Donohue et al. 2002). Antarctic fur seal pups at Cape Shirreff did not display the same pattern, but the perinatal and premolt metabolic rates were already high compared to northern fur seal metabolic rates. The mass-specific DEE of Antarctic fur seals at Cape Shirreff $(828 \pm 59 \mathrm{~kJ} / \mathrm{kg} / \mathrm{d}, n=31)$ was higher than that in similarly aged Antarctic fur seals $(638 \pm 33 \mathrm{~kJ} / \mathrm{kg} /$ d) and sub-Antarctic fur seals (Arctocephalus tropicalis Gray) at Crozet $(533 \pm 33 \mathrm{~kJ} / \mathrm{kg} / \mathrm{d}$; Arnould et al. 2003) and northern fur seals in the Pribilof Islands $(\sim 700 \mathrm{~kJ} / \mathrm{kg} / \mathrm{d}$; Donohue et al. 2002), which is consistent with the colder climate at Cape Shirreff (mean $3^{\circ} \mathrm{C}$ ) compared to Crozet $\left(8^{\circ} \mathrm{C}\right)$ and the Pribilof Islands $\left(6^{\circ} \mathrm{C}\right)$, suggesting that climate influences FMR.

\section{Growth Efficiency}

The growth efficiency of Antarctic fur seal pups at peak lactation ( $\sim 2$ mo of age) is relatively low when compared to other mammalian species (Riek 2007). Most mammals studied fall along a single regression line $\left(y=0.97 x-3.05, \quad r^{2}=0.98, P<\right.$ $0.001, n=39$ ); however, two groups of animals, primates and otariids, fall on a regression line below other mammals $(y=$ $0.94 x-3.65, r^{2}=0.94, P<0.001, n=6$ ), indicating that they are relatively inefficient at translating milk energy into growth (Riek 2007). Growth efficiency ranged from 5.8 to $16.2 \mathrm{~g} / \mathrm{MJ}$, which is similar to the $9.1 \mathrm{~g} / \mathrm{MJ}$ in Australian fur seal pups (Arctocephalus forsteri Lesson; Arnould and Hindell 2002), 10.6 $\mathrm{g} / \mathrm{MJ}$ in California sea lions (Oftedal and Iverson 1987), and 6.8-15.5 g/MJ in northern fur seals (Donohue et al. 2002). Growth efficiency decreased with age, as seen in northern fur seals (Donohue et al. 2002). It was highest during the perinatal period, when pups were not active or fasting. One possible 


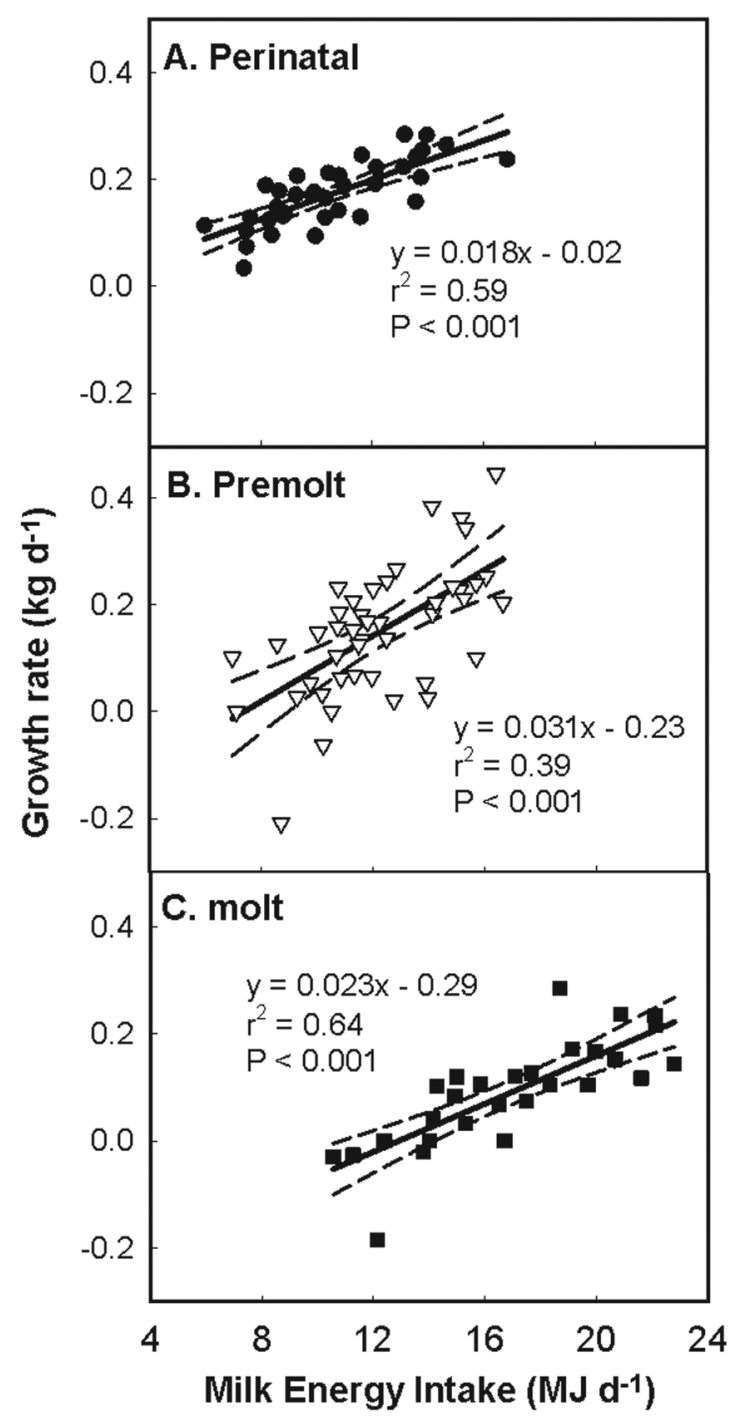

Figure 6. Milk energy intake is positively related to growth rate in Antarctic fur seal pups during all developmental stages ( $A$, perinatal; $B$, premolt; $C$, molt), although growth efficiency decreased with increasing pup age.

explanation for the low growth efficiency at 1 mo of age could be regular fasting and greater activity, particularly in water. Growth efficiency was lowest during the molt when, in addition to periodic fasts and increased time spent in water, pups also expend energy on pelage growth.

\section{Influence of Intrinsic and Extrinsic Factors on FMR and Energy Budgets}

This study provides evidence for intrinsic and extrinsic impacts on energy allocation that varied across development in Antarctic fur seal pups. Weather and pup traits influenced the amount of energy allocated toward maintenance and activity (FMR) when pups were young (newborn and 1 mo of age), but the importance varied with age category. Wind chill was most important during the perinatal period, with pups experiencing colder conditions having the highest metabolic rates. Solar radiation showed some importance during the premolt stage with a tendency for pups experiencing sunnier conditions to have lower metabolic rates. Pups are born into a thermally challenging environment with a dense but wettable pelt and have a thin blubber layer (Blix et al. 1979), which explains why weather was important only when pups were small and before they molted. As pups increased in size and laid down insulative blubber, the effect of weather on FMR declined. This is evident by 1 mo of age, when pup mass and condition had the greatest influence on mass-specific FMR, with larger pups and pups with more blubber having lower mass-specific FMRs. Together these relationships suggest an increased thermoregulatory capacity with development. At 1 mo of age, pups start to spend more time playing in tide pools (B. I. McDonald, personal observation; Baker and Donohue 2000), which results in high rates of heat loss because the natal pup pelage loses its insulative properties when wet (Blix et al. 1979; Donohue et al. 2000; Rutishauser et al. 2004). The elevated FMRs in lighter and thinner pups might be a result of thermoregulatory constraints due to less insulation (lower lipid stores) and a higher surfacearea-to-volume ratio (Donohue et al. 2000; Rutishauser et al. 2004). Additionally, lower mass-specific FMRs in fatter pups may be influenced by reductions in the relative proportion of metabolically active lean tissue (Rea and Costa 1992). During the molt none of the measured variables explained variation in mass-specific FMR. At this age variation in activity levels and associated locomotor costs, which were not measured in this study, may predominate over maintenance components of FMR (Baker and Donohue 2000).

While weather influenced FMR, the magnitude of maternal provisioning and pup mass had the greatest influence on the proportion of energy available for growth during all age categories (figs. 4, 5). Larger pups had less energy available for growth because of their greater whole-animal FMR, while pups that received the greatest amount of milk had the most energy available for growth. This was supported by the positive relationship between milk intake and growth rate at all developmental stages, explaining between $39 \%$ and $64 \%$ of the variation in growth rate (fig. 6). Trip/visit cycle duration did not strongly influence how much energy was available for growth, indicating that increased rates of energy delivery associated with longer trip durations were able to compensate for longer fasting durations in pups, at least in a good year when trips were short.

Previous studies in Antarctic fur seal (Arnould et al. 1996a) and northern fur seal (Donohue 1998) pups found that males and females allocated energy toward lean growth and lipid storage differently, with females depositing greater adipose stores than males. In this study, there were no differences in how males and females allocated energy between metabolic requirements and growth with differences in FMR and energy available for growth attributed to mass differences, not sex differences (table 1); however, we did not investigate how the energy available for growth was allocated toward lean growth and lipid storage. Because there were no differences in condition between 
Table 2: Summary energy budget data from milk dependent young of 12 mammalian species

\begin{tabular}{|c|c|c|c|}
\hline Species and age category & $\begin{array}{l}\text { Adult female } \\
\text { mass }(\mathrm{kg})\end{array}$ & $\begin{array}{l}\text { Energy for } \\
\text { growth (\%) }\end{array}$ & Reference \\
\hline \multicolumn{4}{|l|}{ Carnivora: } \\
\hline \multicolumn{4}{|l|}{ Otariids: } \\
\hline Arctocephalus gazella (Antarctic fur seal) & $35-55$ & & This study ${ }^{\mathrm{a}}$ \\
\hline Newborn (perinatal) & & 59.4 & \\
\hline $1 \mathrm{mo}$ (premolt) & & 23.4 & \\
\hline 2 mo (molt) & & 26.0 & \\
\hline Callorhinus ursinus (northern fur seal) & $40-50$ & & Donohue et al. $2002^{\mathrm{a}}$ \\
\hline 1 mo (premolt), 1995/1996 & & $23 / 37$ & \\
\hline 2 mo (molt), 1995/1996 & & $41 / 20$ & \\
\hline 3 mo (postmolt), 1995/1996 & & $43 / 31$ & \\
\hline Zalophus californianus (California sea lion) & $80-100$ & & Oftedal et al. 1987 \\
\hline $1-4$ wk of age & & 53 & \\
\hline $4-7$ wk of age & & 18 & \\
\hline \multicolumn{4}{|l|}{ Phocidae: } \\
\hline Halichoerus grypus (gray seal) & $140-220$ & & \\
\hline 1-15 d of age (Scotland, 1979) & & 82.3 & Fedak and Anderson $1982^{\mathrm{b}}$ \\
\hline 0-15 d of age (Canada, 1996-1997) & & 70.2 & Mellish et al. $1999^{\mathrm{b}}$ \\
\hline Leptonychotes weddellii (Weddell seal) & $400-600$ & & Tedman and Green $1987^{\mathrm{b}}$ \\
\hline $1-5$ wk of age & & 52.1 & \\
\hline Mirounga angustirostris (northern elephant seal) & $300-500$ & & Crocker et al. $2001^{\mathrm{b}}$ \\
\hline $1-23 \mathrm{~d}$ of age & & 83.6 & \\
\hline \multicolumn{4}{|l|}{ Marsupialia: } \\
\hline Macropus eugenii (tammar wallaby) & 8 & & Green et al. 1988 \\
\hline $4-32 \mathrm{wk}$ & & $23-36$ & \\
\hline Isoodeon macrourus (northern brown bandicoot) & 1.2 & & Merchant et al. 1996 \\
\hline $3-7 \mathrm{wk}$ & & $16.1-39.6$ & \\
\hline Phascolarctos cinereus (koala) & 6 & & Krockenberger et al. $1998^{\mathrm{a}}$ \\
\hline$\sim 260 \mathrm{~d}$ (pouch exit) 1990/1991 & & $46.4 / 9.0$ & \\
\hline \multicolumn{4}{|l|}{ Artiodactyle: } \\
\hline Rangifer tarandus (reindeer) & $80-120$ & & Soppela et al. $2008^{\mathrm{a}}$ \\
\hline $1-2 \mathrm{wk}$ & & 33.5 & \\
\hline $3-4 \mathrm{wk}$ & & 27.1 & \\
\hline \multicolumn{4}{|l|}{ Rodentia: } \\
\hline Neotoma floridana (eastern wood rat) & .230 & & McClure and Randolph 1980 \\
\hline 0-22 d (birth-weaning) & & 43.6 & \\
\hline Sigmodon hispidus (hispid cotton rat) & .110 & & McClure and Randolph 1980 \\
\hline 0-10 d (birth-weaning) & & 20.0 & \\
\hline \multicolumn{4}{|c|}{$\begin{array}{l}\text { Note. Percent of energy budget going toward growth was determined using a variety of methods (see references for details). The two most } \\
\text { common calculations were (1) the method used in this paper, energy for growth }=100 \times \text { (milk energy intake }- \text { energy expenditure)/milk energy } \\
\text { intake and ( } 2 \text { ) the method that used changes in body composition and mass across the age category (see note b below for details). Sources with } \\
\text { no letter after them used a different method. } \\
{ }^{a} \text { Calculated using the method in the article. }\end{array}$} \\
\hline
\end{tabular}

males and females except at birth, this suggests that in this population, at least in the $2 \mathrm{yr}$ of the study, males and females are not allocating the energy available for growth differently.

\section{Implications}

This study indicates that weather influences FMR in young pups, as suggested in gray seal pups (McCafferty et al. 2005).
However, in years with good foraging conditions, such as during this study (based on foraging trip durations; McDonald et al. 2009), this does not affect the amount of energy available for growth. In years of poor foraging conditions, leading to lower milk intake in pups (Krockenberger et al. 1998; Donohue et al. 2002), weather may have greater impacts, especially in young pups (Blix et al. 1979). This was suggested in northern fur seals when the energy budgets were significantly different 
between two study years because lower milk intake in one year resulted in lower lipid storage, causing pups to allocate more energy toward thermoregulation (Donohue et al. 2002). To allocate adequate energy toward growth and lipid storage, pups may swim less, thereby sacrificing development of foraging skills. The level of energy stores needed during the dependency period and at weaning may be more important than benefits obtained from preweaning development of dive capacity and foraging skills (Guinet et al. 2005; Bennett et al. 2010; Verrier et al. 2011). In phocids, smaller pups depart on their first trip to sea at a younger age, resulting in them departing with less developed $\mathrm{O}_{2}$ storage capacity in order to maximize their energy reserves at departure (Noren and Mangel 2004; Noren et al. 2008; Bennett et al. 2010), and sub-Antarctic fur seal pups decreased the amount of time spent swimming in winter in order to offset the low maternal provisioning rate in winter (Guinet et al. 2005; Verrier et al. 2011). Antarctic fur seal pups have much less time to develop foraging skills (4 mo vs. 10$12 \mathrm{mo}$ ); therefore, such a decrease in activity may have greater negative impacts on their ability to transition successfully to nutritional independence.

The Antarctic Peninsula is one of the regions on earth experiencing the greatest rate of climate change. In the past 50 years mean annual temperature increased by $\sim 3^{\circ} \mathrm{C}$ (Vaughan et al. 2003). Additionally, the southern westerlies (the circumpolar winds between $30^{\circ}$ and $65^{\circ} \mathrm{S}$ ) are strengthening and moving south (Marshall 2002). If these trends continue, the conditions at Cape Shirreff will become warmer, but conditions will also include increased rainfall, higher wind speeds, and likely an increase in overwinter snowfall. Although the projected changes are similar to current conditions in much of the Antarctic fur seal range (e.g., South Georgia), the current climate at Cape Shirreff may be beneficial to pups, and the projected environmental conditions could lead pups to allocate more energy toward thermoregulation. If females are not able to meet the increase in pup energetic requirements, pups may sacrifice the development of foraging skills to ensure weaning with greater body stores. This could potentially lead to a decline in juvenile survival and result in demographic effects.

In summary, our results indicate that both intrinsic and extrinsic factors influence the FMR and energy available for growth in dependent pups. Increased maternal energetic investment does lead to greater growth rates in pups, but other factors such as pup traits and environmental conditions can be important in determining how much energy is available for growth. Most of the energy the pups received from their mothers is used to meet metabolic demands, including thermoregulation and behavior, emphasizing the potential trade-offs between physiological regulation in the polar climate, activities required to acquire foraging skills, and growth.

\section{Acknowledgments}

We thank all those who assisted with the collection of the data, in particular C. Champagne, R. Haner, and S. Seganti. Logistical support was provided by the U.S. Antarctic Marine Living Resources (AMLR) Program, the National Science Foundation (NSF) U.S. Antarctic Program, and Raytheon Polar Services. This research was funded by the U.S. AMLR Program and NSF Office of Polar Programs grant 0440687 to D.P.C, D.E.C., and M.E.G. B.I.M. was supported by the U.S. Environmental Protection Agency (EPA) under the Science to Achieve Results Graduate Fellowship Program and an NSF graduate fellowship. EPA has not officially endorsed this publication, and the views expressed herein may not reflect the views of the EPA.

\section{Literature Cited}

Arnould J.P.Y. and I.L. Boyd. 1995. Temporal patterns of milk production in Antarctic fur seals (Arctocephalus gazella). J Zool (Lond) 237:1-12.

Arnould J.P.Y., I.L. Boyd, D.R. Rawlins, and M.A. Hindell. 2001. Variation in maternal provisioning by lactating Antarctic fur seals (Arctocephalus gazella): response to experimental manipulation in pup demand. Behav Ecol Sociobiol 50:461466.

Arnould J.P.Y., I.L. Boyd, and D.G. Socha. 1996a. Milk consumption and growth efficiency in Antarctic fur seal (Arctocephalus gazella) pups. Can J Zool 74:254-266.

Arnould J.P.Y., I.L. Boyd, and J.R. Speakman. 1996b. Measuring the body composition of Antarctic fur seals (Arctocephalus gazella): validation of hydrogen isotope dilution. Physiol Zool 69:93-116.

Arnould J.P.Y. and M.A. Hindell. 2002. Milk consumption, body composition and pre-weaning growth rates of Australian fur seal (Arctocephalus pusillus doriferus) pups. J Zool (Lond) 256:351-359.

Arnould J.P.Y., S.P. Luque, C. Guinet, D.P. Costa, J. Kingston, and S.A. Shaffer. 2003. The comparative energetics and growth strategies of sympatric Antarctic and subantarctic fur seal pups at Iles Crozet. J Exp Biol 206:4497-4506.

Baker J.D. and M.J. Donohue. 2000. Ontogeny of swimming and diving in northern fur seal (Callorhinus ursinus) pups. Can J Zool 78:100-109.

Barber-Meyer S.M. and L.D. Mech. 2008. Factors influencing predation on juvenile ungulates and natural selection implications. Wildl Biol Pract 4:8-29.

Barlow J. and P.L. Boveng. 1991. Modeling mortality for marine mammal populations. Mar Mamm Sci 7:50-65.

Beauplet G., C. Barbraud, M. Chambellant, and C. Guinet. 2005. Interannual variation in the post-weaning survival of subantarctic fur seals: influence of pup sex, growth rate, and environmental conditions. J Anim Ecol 74:1160-1172.

Bekoff M. 1988. Motor training and physical fitness: possible shortcomings and long-term influences on the development of individual differences in behavior. Dev Psychobiol 21:601612.

Bennett K.A., B.J. McConnell, S.E.W. Moss, J.R. Speakman, P.P. Pomeroy, and M. Fedak. 2010. Effects of age and body mass and development of diving capabilities of gray seal pups: 
costs and benefits of the postweaning fast. Physiol Biochem Zool 83:911-923.

Blix A.S., L.K. Miller, M.C. Keyes, H.J. Grav, and R. Elsner. 1979. Newborn northern fur seals (Callorhinus ursinus): do they suffer from cold? Am J Physiol 236:322-327.

Blix A.S. and J.B. Steen. 1979. Temperature regulation in newborn polar homeotherms. Physiol Rev 59:285-304.

Burns J.M. 1999. The development of diving behavior in juvenile Weddell seals: pushing physiological limits in order to survive. Can J Zool 77:737-747.

Burns J.M. and M.A. Castellini. 1996. Physiological and behavioral determinants of the aerobic dive limit in Weddell seal (Leptonychotes weddellii) pups. J Comp Physiol 166:473483.

Cameron E.Z. 2008. Maternal investment results in better foal condition through increased play behavior in horses. Anim Behav 76:1511-1518.

Chappell M.A. and D.S.I. Holsclaw. 1984. Effects of wind on thermoregulation and energy balance in deer mice (Peromyscus maniculatus). J Comp Physiol 154:619-625.

Clutton-Brock T.H., M. Major, and F.E. Guinness. 1985. Population regulation in male and female red deer. J Anim Ecol 54:831-846.

Costa D.P. 1987a. Isotopic methods for quantifying material and energy intake of free-ranging marine mammals. Pp. 4366 in A.C. Huntley, D.P. Costa, G.A.J. Worthy, and M.A. Castellini, eds. Approaches to marine mammal energetics. Society for Marine Mammalogy, Lawrence, KS.

-1987b. Methods for studying the energetics of freely diving animals. Can J Zool 66:45-52.

- 1993. The relationship between reproductive and foraging energetics and the evolution of the Pinnipedia. Pp. 293-314 in I.L. Boyd, ed. Marine mammals: advances in behavioural and population biology. Symposia of the Zoological Society of London. Oxford University Press, New York.

Coulson T., S. Albon, F.E. Guinness, J. Pemberton, and T.H. Clutton-Brock. 1997. Population substructure, local density, and calf winter survival in red deer (Cervus elaphus). Ecology 78:852-863.

Crocker D.E., J.D. Williams, D.R. Costa, and B.J. Le Boeuf. 2001. Maternal traits and reproductive effort in northern elephant seals. Ecology 82:3541-3555.

Culik B., D. Adelung, M. Heise, R.P. Wilson, N.R. Coria, and H.J. Spairani. 1989. In situ heart rate and activity of incubating Adélie penguins (Pygoscelis adeliae). Polar Biol 9:365370.

Donohue M.J. 1998. Energetics and development of northern fur seal, Callorhinus ursinus, pups. PhD diss. University of California, Santa Cruz.

Donohue M.J., D.P. Costa, E. Goebel, G.A. Antonelis, and J.D. Baker. 2002. Milk intake and energy expenditure of freeranging northern fur seal, Callorhinus ursinus, pups. Physiol Biochem Zool 75:3-18.

Donohue M.J., D.P. Costa, M.E. Goebel, and J.D. Baker. 2000. The ontogeny of metabolic rate and thermoregulatory ca- pabilities of northern fur seal, Callorhinus ursinus, pups in air and water. J Exp Biol 203:1003-1016.

Fadely B.S., G.A.J. Worthy, and D.P. Costa. 1990. Assimilation efficiency of northern fur seals determined using dietary manganese. J Wildl Manag 54:246-251.

Fagen R.M. 1981. Animal play behavior. Oxford University Press, New York.

Fedak M.A. and S.S. Anderson. 1982. The energetics of lactation: accurate measurements from a large wild mammal, the grey seal (Halichoerus grypus). J Zool (Lond) 198:473-479.

Festa-Bianchet M., J.T. Jorgensen, C.H. Berubé, C. Portier, and W.D. Wishart. 1997. Body mass and survival of bighorn sheep. Can J Zool 75:1372-1379.

Festa-Bianchet M., J.T. Jorgenson, and D. Réale. 2000. Early development, adult mass, and reproductive success in bighorn sheep. Behav Ecol 11:633-639.

Gastebois C., M. Viviant, and C. Guinet. 2011. Ontogeny of aquatic behaviours in Antarctic fur seal (Arctocephalus gazella) pups in relation to growth performances at Kerguelen Islands. Polar Biol 34:1097-1103.

Green B., J.C. Merchant, and K. Newgrain. 1988. Milk consumption and energetics of growth in pouch young of the tammar wallaby, Macropus eugenii. Aust J Zool 36:217-227.

Guinet C., N. Servera, T. Deville, and G. Beauplet. 2005. Changes in subantarctic fur seal pups' activity budget and diving behaviours throughout the rearing period. Can J Zool 83:962-970.

Hall A.J., B.J. McConnell, and R.J. Barker. 2001. Factors affecting first-year survival in grey seals and their implications for life history strategy. J Anim Ecol 70:138-149.

Hauser M.D. 1994. The transition to foraging independence in free-ranging vervet monkeys. Pp. 165-202 in B.G. Galef, M. Mainardi, and P. Valsecchi, eds. Behavioral aspects of feeding. Harwood Academic, Chur, Switzerland.

Hill R.W. 1983. Thermal physiology and energetics of Peromyscus; ontogeny, body temperature, metabolism, insulation, and microclimatology. J Mammal 64:19-37.

Horning M. and F. Trillmich. 1997. Ontogeny of diving behaviour in the Galápagos fur seal. Behaviour 134:1211-1257.

Hou C., W. Zuo, M.E. Moses, W.H. Woodruff, J.H. Brown, and G.B. West. 2008. Energy uptake and allocation during ontogeny. Science 322:736-739.

Jorgensen C., C. Lydersen, O. Brix, and K.M. Kovacs. 2001. Diving development in nursing harbour seal pups. J Exp Biol 204:3993-4004.

Krockenberger A.K., I.D. Hume, and S.J. Cork. 1998. Production of milk and nutrition of the dependent young of freeranging koalas (Phascolarctos cinereus). Physiol Zool 71:4556.

Lindström J. 1999. Early development and fitness in birds and mammals. Trends Ecol Evol 14:343-348.

Marshall G.J. 2002. Trends in the southern annular mode from observations and reanalysis. J Clim 16:4134-4143.

McCafferty D.J., S. Moss, K. Bennett, and P.P. Pomeroy. 2005. Factors influencing the radiative surface temperature of grey 
seal (Halichoerus grypus) pups during early and late lactation. J Comp Physiol 175:423-431.

McClure P.A. and J.C. Randolph. 1980. Relative allocation of energy to growth and development of homeothermy in the eastern wood rat (Neotoma floridana) and hispid cotton rat (Sigmodon hispidus). Ecol Monogr 50:199-220.

McDonald B.I. 2009. The reproductive energetics of Antarctic fur seals (Arctocephalus gazella): influence of maternal traits and foraging behavior on maternal investment. $\mathrm{PhD}$ diss. University of California, Santa Cruz.

McDonald B.I., M.E. Goebel, D.E. Crocker, Y. Tremblay, and D.P. Costa. 2009. Effects of maternal traits and individual behavior on the foraging strategies and provisioning rates of an income breeder, the Antarctic fur seal. Mar Ecol Prog Ser 394:277-288.

McNab B.K. 2002. The physiological ecology of vertebrates: a view from energetics. Cornell University Press, Ithaca, NY.

Mellish J.-A.E., S.J. Iverson, and W.D. Bowen. 1999. Variation in milk production and lactation performance in grey seals and consequences for pup growth and weaning characteristics. Physiol Biochem Zool 72:677-690.

Merchant J.C., J.A. Libke, and K. Newgrain. 1996. Milk consumption and estimates of growth energetics in pouch young of the northern brown bandicoot, Isoodon macrourus (Peramelidae, Marsupialia), in captivity. J Zool (Lond) 238:483494.

Munn A.J. and T.J. Dawson. 2006. Forage fibre digestion, rates of feed passage and gut fill in juvenile and adult red kangaroos Macropus rufus Desmarest: why body size matters. J Exp Biol 209:1535-1547.

Nagy K.A. and D.P. Costa. 1980. Water flux in animals: an analysis of potential errors in the tritiated water method. Am J Physiol 238:R446-R473.

Nislow K.H. and D.I. King. 2006. Transition from maternal provisioning: crunch time in vertebrate life histories? J Zool (Lond) 269:401-402.

Noren D.P. and M. Mangel. 2004. Energy reserve allocation in fasting northern elephant seal pups: inter-relationships between body condition and fasting duration. Funct Ecol 18: 233-242.

Noren S.R., D.J. Boness, S.J. Iverson, J.I. McMillan, and W.D. Bowen. 2008. Body condition at weaning affects the duration of the postweaning fast in gray seal pups (Halichoerus grypus). Physiol Biochem Zool 81:269-277.

Oftedal O.T. and S.J. Iverson. 1987. Hydrogen isotope methodology for measurement of milk intake and energetics of growth in suckling young. Pp. 67-96 in A.C. Huntley, D.P. Costa, G.A.J. Worthy, and M.A. Castellini, eds. Approaches to marine mammal energetics. Society for Marine Mammalogy, Lawrence, KS.

Oftedal O.T., S.J. Iverson, and D.J. Boness. 1987. Milk and energy intakes of suckling California sea lion (Zalophus californianus) pups in relation to sex, growth, and predicted maintenance requirements. Physiol Zool 60:560-575.

Ortiz C.L., D.P. Costa, and B.J. Le Boeuf. 1978. Water and energy flux in elephant seal pups fasting under natural conditions. Physiol Zool 51:166-178.

Ortiz C.L., B.J. Le Boeuf, and D.P. Costa. 1984. Milk intake of elephant seal pups: an index of parental investment. Am Nat 124:416-422.

Power T.G. 2000. Play and exploration in children and animals. Erlbaum, Mahwah, NJ.

Rea L.D. and D.P. Costa. 1992. Changes in standard metabolism during long-term fasting in northern elephant seal pups (Mirounga angustirostris). Physiol Zool 65:97-111.

Richmond J.P., J.M. Burns, and L.D. Rea. 2006. Ontogeny of total body oxygen stores and aerobic dive potential in Steller sea lions (Eumetopias jubatus). J Comp Physiol B 176:535545.

Riek A. 2007. Relationship between milk energy intake and growth rate in suckling mammalian young at peak lactation: an updated meta-analysis. J Zool (Lond) 274:160-170.

Rutishauser M.R., D.P. Costa, M.E. Goebel, and T.M. Williams. 2004. Ecological implications of body composition and thermal capabilities in young Antarctic fur seals (Arctocephalus gazella). Physiol Biochem Zool 77:669-681.

Schmidt-Nielsen K. 1979. Animal physiology: adaptation and environment. 2nd ed. Cambridge University Press, Cambridge.

Soppela P., S. Timlin, H. Visser, and M. Nieminen. 2008. The estimation of milk intake and energy expenditure of reindeer calves by the doubly-labelled water method. Acta Physiol 193: 27.

Speakman J.R. 1997. Doubly labelled water: theory and practice. Chapman \& Hall, London.

Spinka M., R.C. Newberry, and M. Bekoff. 2001. Mammalian play: training for the unexpected. Q Rev Biol 76:141-168.

Sullivan K.A. 1988. Ontogeny of time budgets in yellow-eyed juncos: adaptation to ecological constraints. Ecology 57:118124.

Tedman R. and B. Green. 1987. Water and sodium fluxes and lactational energetics in suckling pups of Weddell seals (Leptonychotes weddellii). J Zool 212:29-42.

Vaughan D.G., G.J. Marshall, W.M. Connolley, C. Parkinson, R. Mulvaney, D.A. Hodgson, J.C. King, C.J. Pudsey, and J. Turner. 2003. Recent rapid regional climate warming on the Antarctic Peninsula. Clim Change 60:243-274.

Verrier D., C. Guinet, M. Authier, Y. Tremblay, S. Shaffer, D.P. Costa, R. Groscolas, and J.P.Y. Arnould. 2011. The ontogeny of diving abilities in subantarctic fur seal pups: developmental trade-off in response to extreme fasting? Funct Ecol 25:818-828.

Weathers W.W. and K.A. Sullivan. 1989. Juvenile foraging proficiency, parental effort, and avian reproductive success. Ecol Monogr 59:223-246.

Young R.A. 1976. Fat, energy, and mammalian survival. Am Zool 16:699-710.

Zuur A.F., E.N. Ieno, N. Walker, A.A. Savelieu, and G.M. Smith. 2009. Mixed effects models and extensions in ecology with R. 1st ed. Springer Science and Business Media, New York. 
Copyright of Physiological \& Biochemical Zoology is the property of University of Chicago Press and its content may not be copied or emailed to multiple sites or posted to a listserv without the copyright holder's express written permission. However, users may print, download, or email articles for individual use. 